\title{
A Literature Review of the Perspectives of CEO Pay: An Analysis of Issues and Controversies
}

\author{
Faitira Manuere \\ Department of entrepreneurship and Business Management \\ Chinhoyi University of Technology, Chinhoyi Zimbabwe \\ Precious Hove \\ Department of entrepreneurship and Business Management \\ Chinhoyi University of Technology, Chinhoyi Zimbabwe
}

Received: Jul. 30, 2018 Accepted: Oct. 9, 2018 Online published: Oct. 24, 2018

doi:10.5296/jpag.v8i4.13817ＵRL: https://doi.org/10.5296/jpag.v8i4.13817

\begin{abstract}
The purpose of this paper is to review the literature on various theories that are used in organisations today to determine executive compensation. This paper analyses the relevance of the theories that are used to determine CEO compensation in modern corporations. The paper makes an attempt to review extensively the literature on CEO compensation. This paper looks at the concerns of sixteen theories of executive compensation. This paper further analyses the special features that are associated with CEO pay. These features help us to understand the problems that experts on executive pay experience when they try to define the exact CEO pay when compared to other rewards that are non financial. The drivers of executive pay are quantified and qualified in order to provide the conceptual background needed to understand the core factors that determine executive pay. Therefore the role of institutional investors in driving managerial salary is explored in detail. Finally, the effects of firm size and good corporate governance on executive pay are carefully analysed.
\end{abstract}

Keywords: structure of executive pay, chief executive officer, compensation practices in corporations, the agency problem, relevance of the theories used, mechanisms of corporate governance, institutional investors and firm size.

\section{Introduction}

The literature on executive remuneration advances the argument that executive compensation 
is premised on the philosophy that the interests of the board should be aligned to the interests of the shareholders (Aggarwal and Samwick, 1999). The doctrine of managerialism posits that the separation of ownership from control creates a divergence of interests between the management and owners (Tosi et al 2000). Consequently managers concentrate on getting more pay, power and prestige and in this way they can concentrate on maximising firm size rather than the value of the company (Tosi et al 2000). The size of the company is used to justify the level of executive pay (Jensen and Meckling, 1976). Some authorities in corporate governance believe that shareholders can control the management by using internal control systems, such as, auditing, budget restrictions and compensation systems (Jensen and Murphy (1990). Ozkan (2007) argues that there is a positive relationship between executive compensation and corporate performance. On the other hand the study by Brick et al (2005) reveals that there is strong negative correlation between executive compensation and corporate performance. Similar studies carried out by Zhou (2000) established that executive compensation has a positive relationship with firm size although compensation depends on corporate performance. Shah et al (2009) carried out a study to investigate the factors that influence the pay levels of executives in corporations, and the findings revealed that the following factors were responsible; 1) size of the firm, 2) CEO duality, 3) board independence, 4) board size, 5) ownership structure, 6) ownership concentration and 7) audit committee independence.

Berkema and Mejia (1998) conducted a study to investigate the factors that influence the pay levels of CEOs and the findings show that the factors are; market forces, the ownership structure of the firm, size of block holders and the existence of remuneration committees. Berkema et al (1998) argue that the separation of control and management is critical when it comes to making decisions on CEO compensation. In other words the composition of the remuneration committee should be such that the majority of them are outside directors (Berkema et al, 1998). The literature on corporate governance suggests that board members have an important role in setting CEO compensation, controlling future projects and making decisions that affect the replacement of CEOs (Raheja, 2005). The executive pay structure has several components; such as, bonus stock options, stocks, pensions and perquisites (Finkelstein and Boyd 1998). Murphy (1999) argues that the elements that constitute CEO pay are not homogenous in terms of pay practises across firms and industries. Murphy (1999) identifies four basic components of executive pay: a base salary, an annual bonus linked to accounting performance, stock options, and long term incentive plans. The packages of most executive compensation consist of several components, such as, pay-outs for long run incentive plans; restrictictive stock grants, pension plans, various perquisites, and severance payments (Jensen and Murphy, 1990; Friedman and Jenter, 2010).

\section{The Review of Related Literature}

The literature on executive compensation presents sixteen theories which can be used to interrogate the subject of CEO remuneration and the sixteen theories are grouped into three distinct approaches, namely 1) the value approach, 2) the agency approach, and 3)the symbolic approach ( Gomez- Mejia, 1994; Balsam, 2002). Table 1, below, presents groups of theories used in determining CEO pay scales. 
Table 1. CEO compensation and related theories

\begin{tabular}{|c|c|c|}
\hline Value Approach Theories & $\begin{array}{ll}\text { Agency } & \text { Approach } \\
\text { Theories } & \\
\end{array}$ & $\begin{array}{l}\text { Symbolic } \quad \text { Approach } \\
\text { Theories }\end{array}$ \\
\hline $\begin{array}{l}\text { 1. Marginal productivity } \\
\text { theory }\end{array}$ & $\begin{array}{l}\text { 1. Complete contract } \\
\text { theory }\end{array}$ & 1. Tournament theory \\
\hline 2. Efficiency wage theory & 2. Prospect theory & 2. Figurehead theory \\
\hline 3. Human capital theory & 3. Managerial theory & 3. Stewardship theory \\
\hline 4. Opportunity cost theory & 4. Hegemony theory & 4. Crowding-out theory \\
\hline \multirow[t]{3}{*}{ 5. Superstar theory } & & $\begin{array}{ll}\text { 5. } & \text { Socially enacted } \\
\text { proportionality theory }\end{array}$ \\
\hline & & 6. Social comparison \\
\hline & & $\begin{array}{l}\text { 7. Implicit psychological } \\
\text { contract theory }\end{array}$ \\
\hline
\end{tabular}

Source: Gomez -Mejia (1994)

\subsection{The Symbolic Approach}

The symbolic approach consists of theories that consider executive pay as a socially constructed symbol to explain the status, dignity, prestige and the high esteem accorded to the role of the CEO in the organisation (Gomez and Mejia, 194). The symbolic approach consists of theories such as, 1) the tournament theory, 2) figurehead theory, 3) stewardship theory 4) crowding-out theory, 5) implicit/psychological contract theory, 6) socially enacted proportionality theory and 7) social comparison theory. The tournament theory considers pay as a prize in a contest (Lazear and Rosen, 1981). The figurehead theory sees the organisation as a place where political conflicts do exist among various political groups, and that those groups of people who succeed in manoeuvring others politically get rewarded through executive compensation (Ungson and Steers, 1984). The stewardship theory suggests that executive pay scales are premised on the philosophy that the CEO and other members of the board have agreed to align their interests to those of the shareholders and this cooperative behaviour is rewarded accordingly (Donaldson et al, 1991). The crowd-out theory is premised on the philosophy that there must be a balance between intrinsic motivation and extrinsic motivation in order to avoid the negative effects created by both high salary scales and lower salary scales (Frey, 1997).

The psychological contract theory suggests that the principal (the shareholders) and the agent (the board of directors) enter into a relational contract in which the principal is obliged to pay the agent a fair and reasonable salary and in turn the agent is required to meet his or her work obligations in a manner that justifies the compensation pay scales (Kidder and Buchholtz, 2002). The socially enacted proportionality theory argues that the salaries that employees get come from the same source and that the source is considered a pie that has several partitions. Each partition in the pie resembles a job position in the organisation. Therefore the pie is divided proportionally according to the responsibilities that characterise a job position. Those with jobs that require more decision making get the highest share of the pie (Simon, 1957). The social comparison theory argues that executive pay is a function of normative judgement 
by the board members (Goodman, 1974). Executives use their own pay levels, experiences and motivations as reference points (Gomez-Mejia, 1994; O’Reily et al, 1988).

\subsection{The Value Approach}

The value approach is based on the laws of economics of supply and demand as a means for determining executive compensation (Roberts, 1956). The value approach is supported by five theories, such as, 1) the marginal productivity theory, 2) efficiency wage theory, 3) human capital theory, 4) opportunity cost theory, and 5) superstar theory (Gomez-Mejia 1994). The marginal productivity theory relates the services of the executives to any other input factor of production (Roberts, 1956). Thus executive pay is equal to the executive marginal revenue products (Roberts, 1956). The human capital theory is based on the philosophy that executive productivity is highly influenced by the educational background as well as the breadth of knowledge possessed by the executive (Combs an Skill, 2003). The executive who has more knowledge and skills has a higher human capital base (Combs and Skill, 2003). Therefore an executive with massive quantities of knowledge and skill is paid more for his or her job (Combs and Skill,2003).

The efficiency wage theory suggests that executives will work harder when they are given a salary which is above the market level of industry (Prendergast, 1999). Executives who are paid higher than the market level salary will not think about leaving the company and executives' turnover decreases whereas productivity increases (Balsam, 2002). The opportunity cost approach is based on the doctrine of attracting, keeping and retaining executives through attractive executive pay levels (Thomas, 2002). The superstar theory argues that there is no perfect substitution for better talent (Rosen, 1981). Therefore the demand for better talent is ever rising (Rosen, 1981).

\subsection{The Agency Problem}

The optional contract theory suggests that executive pay is used to align the interest of the executives to those of the shareholders (Gomez- Mejia and Wiseman, 1997). Basically, the agency problem reflects the magnitude of the conflict between the executives and the shareholders as a result of a divergence of interests (Gomez- Mejia and Wiseman, 1997). Executive pay structures are therefore used to reconstruct the behaviours, interests and perceptions of executives to reflect the interest of the shareholders (Gomez- Mejia and Wiseman, 1997). The prospect theory points out that one of the critical responsibilities of the CEO is risk -taking (Balsam, 2002). The prospect theory suggests that there is a limit to which the CEO is willing to take more risks (Balsam, 2002). Therefore executive pay levels reflect the willingness of the CEO to take more risks (Balsam, 2002). The managerial power theory presupposes that the executive has natural powers to make decisions related to their pay structures (Jensen and Meckling, 1976). The class hegemony theory suggests executives share power with executives from other organisations in order to protect their privileges and the wealth of their class ((Gomez- Mejia 1994).

\subsection{Other Theories of Compensation}

Figure 1, shows three executive compensation theories, namely, reinforcement and 


\section{Macrothink}

expectancy theory, equity theory, and agency theory.

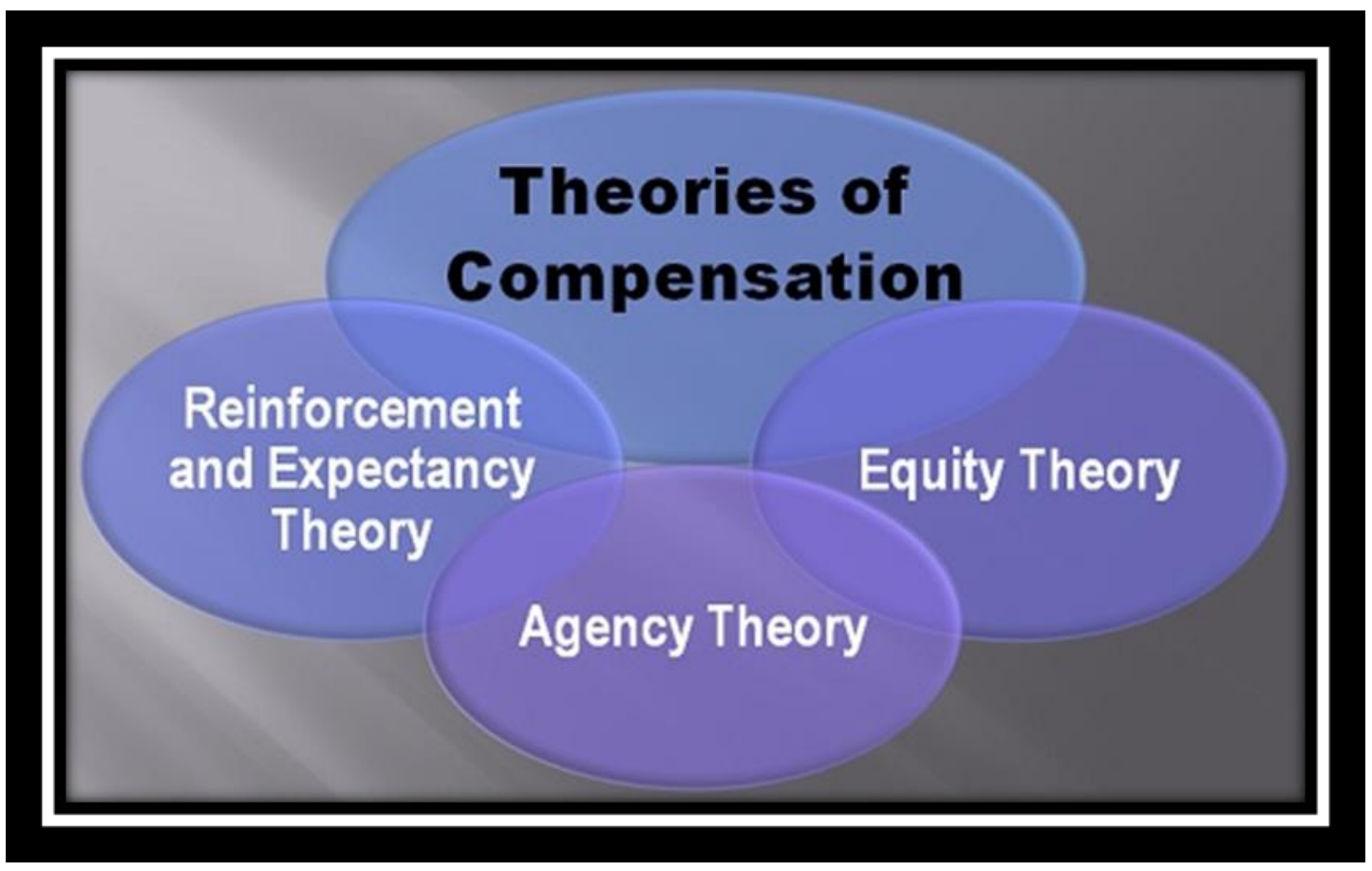

Figure 1. Theories of executive compensation

Source: Jenson and Murphy, 1990).

\subsubsection{Reinforcement and Expectancy Theory}

This theory is based on behavior that is repeated. An employee who gets rewarded for handwork will continue to work hard in order to receive the same reward all the time. In the same way, employers will continue to reward employees who show adequate dedication to duty. This theory is prominent where performance appraisal systems are used to reward hard -work.( (Greenberg, 1986;Parijat and Bagga,2014; Jensen and Murphy,1990).

\subsubsection{Equity Theory}

This theory talks about equity, fairness and justice in the way salaries are distributed to the employees in the organization. Some employees may feel that they are not getting enough for the work they do ((Greenberg, 1986).This kind of feeling will result in the disgruntled employees not working hard, with the result that productivity is reduced. Some employees will embark on a go-slow to register their displeasure for not getting a salary level they think they deserve (Greenberg, 1986).

\subsubsection{Agency Theory}

The agency theory argues that a company has primary social stakeholders who deserve to benefit from the proceeds of the company. Primary social stakeholders include employees, employers, customers, sellers, buyers, the board of directors and the management team (Parijat and Bagga, 2014). The people who receive salaries from the organization are employees, 


\section{Macrothink Institute ${ }^{\mathrm{TM}}$}

employers, the executive directors, and the management team or the employers. According to the agency theory, both employees and employers are the critical stakeholders of the company and the salaries paid to them constitute the agency costs (Parijat and Bagga, 2014). Employees will increase agency costs whereas employers will reduce them. Therefore the agency cost theory argues that salaries are used to align the interests of both parties to the interests of shareholders, as shown in Figure 2, below:

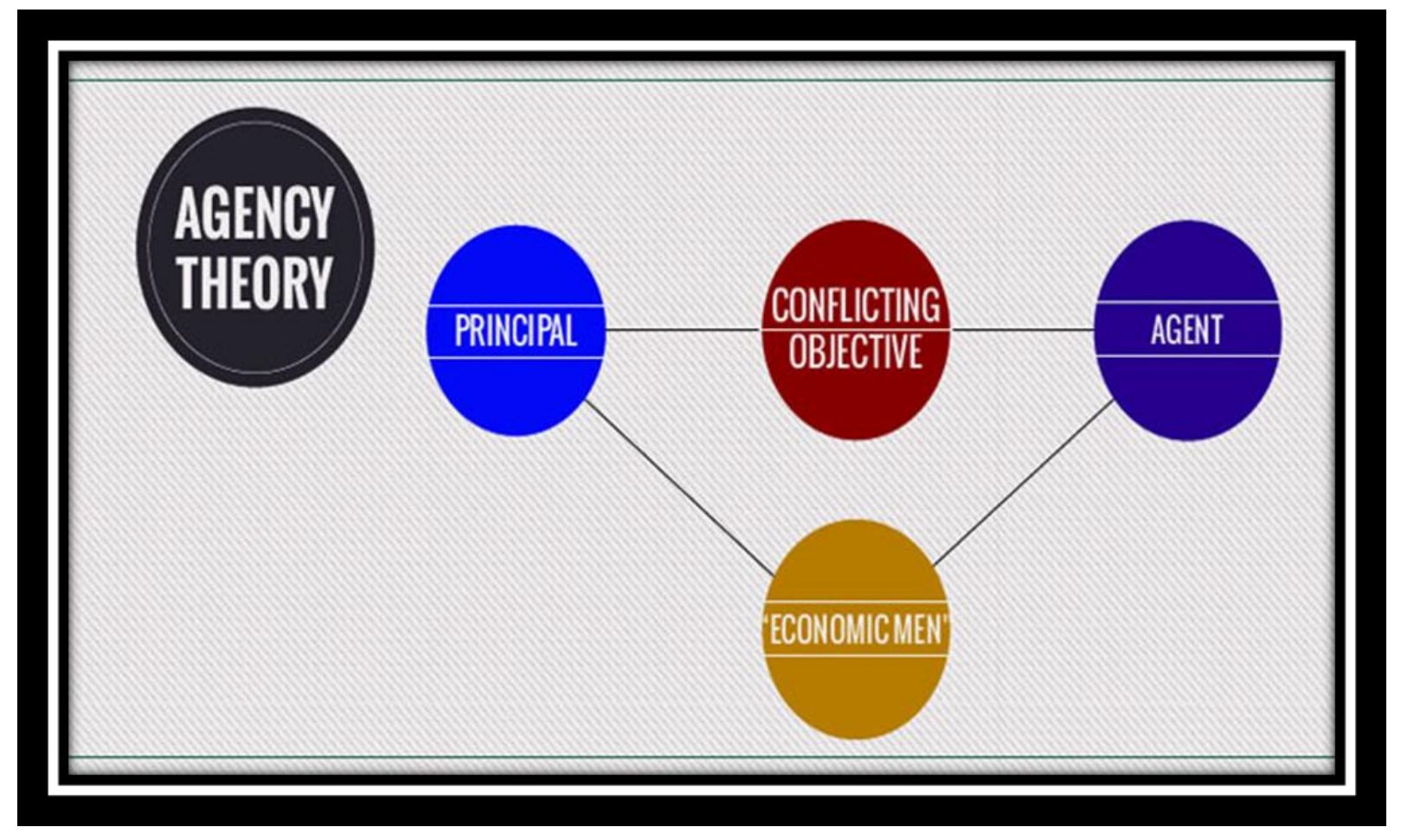

Figure 2. The agency theory of compensation

Source: Jenson and Murphy (1990).

Figure 2 shows two critical parties to corporate governance, namely, the shareholders and the board of directors. The shareholders are called the principals whereas the board of directors are the agents. The shareholders are the owners of the company whereas the board of directors are hired to run the affairs of the company on behalf of the principals, who are the shareholders.

\section{An Assessment of the Approaches}

Academic scholars in corporate governance argue that the three approaches (the value approach, the agency approach and the symbolic approach) show a very weak relationship between executive compensation and company performance, (Gomez- Mejia ,1994). The value approach makes use of economic theories to explain the disparities that exist among the pay levels of executives. However markets have limited capacity to influence the decision making process on executive pay levels (Kay, 2000). CEOs wield much power to influence the board of directors and the decision making process when negotiating their own pay (Aquilera and Jackson, 2003). It must also be noted that executive pay is also influenced by external forces, 
such as, the government, financial institutions, investors, labour unions and other firms ( Jensen and Murphy, 2004). The executive pay theories often neglect the role of the external factor in decision making process that finally translate into executive compensation (Zingales, 1998). Corporate governance practices are different from one organisation to another and the influence of such practices on executive pay levels cannot be ignored (Jensen and Murphy, 1990). Most empirical research on executive pay makes use of data from developed countries, such as the Unite States of America (USA) and generalisations and conclusions of theories imply that the USA example is taken to be a worldwide standard (Kaplan , 1995). Authorities in corporate governance do admit that there are other socially constructed corporate governance arrangements that are used by the board of directors to make a determination on executive pay levels (Roe, 2003). Since the agency theory is dominantly used to determine executive pay levels, other conditions and arrangements made by the board of directors are not given due considerations (Zingales, 1998).

\section{Characteristics of CEO Pay}

The remuneration of CEOs is characteristics by a number of concepts that need careful analysis or evaluation. This means that it is difficult to have quantitative and qualitative measurement scales that could accurately predict the CEO pay structures that should be established in companies (Antle and Smith, 1985). CEO pay structures in companies are not standard. The remuneration of CEOs is associated with other rewards that are not financial in nature and this situation makes it difficult to define the exact basic salary that constitutes CEO compensation. In other words the concept of pay is just but one picture of the financial rewards that accrue to CEOs. In fact CEOs, receive a myriad of both financial and non-financial rewards that make it difficult to compute the exact monetary rewards that CEOs receive. According to Finikelstein and Hambrick (1988) CEOs receive various remuneration packages such as "salary, bonus, benefits, stock options, pension contributions, deferred income and long term contingent compensation." Finikelstein and Hambrick (1988) further argue that the administration of CEO compensation packages creates a number of problems. The first problem has to do with relating compensation to a specific timeframe. CEOs may get a stock option this year but may be able to use the stock option two years later. The problem then arises in trying to define the compensation obtained from the options each subsequent year (Finkelstein and Hambrick, 1988). The second problem concerns the definition of a particular salary structure as the base (Finkelstein and Hambrick, 1988).

\section{Drivers of CEO Pay}

According to Kim and Tucker (2014) in James (2014) the most important drivers of CEO pay are, firm size, the quality and quantity of workers, gender, the return on assets and the implementation of good corporate governance in an organization. Studies on executive pay have revealed that there is no correlation between gender and executive pay in organizations (Kim and Tucker, 2014). Studies on executive compensation have shown that there is no agreement on whether or not theories on executive pay constitute the main drivers of CEO compensation (Kim and Tucker). Since the board of directors play a critical role in determining CEO pay, it can be difficult to define the exact factors that drive CEO pay in 
modern organizations. Finikelstein and Hambrick (1988) in James (2014) argue that the drivers of CEO compensation include, "market factors, the power and preferences of the board and CEO prerogatives."

\subsection{Market Forces}

Experts on CEO compensation argue that the boards of directors use several environmental factors to construct a pay structure for the executives. First and foremost the supply and demand factors are used to define the executive pay structure. Secondly, the executive pay structure is based on both the physical and emotional sacrifices made by the board of directors to increase firm performance. The board of directors possess certain rare skills or competencies that are highly demanded by the firm in the industry and therefore CEO pay is a direct "response" to the demand and supply of executive skills that are in short supply (Ciscel and Carroll, 1980). According to Frank (1984) the executives are paid for their productivity in the long run.

\subsection{Power and Preferences}

According to Finkelstein and Hambrick (1988) in James (2014) the politics of the organization are the main drivers of CEO pay. Shareholders exercise ownership of company but actual control of the company is in the hands of the board of directors. Consequently, the shareholders do not have adequate information concerning the day to day management of the company. Secondly the interests of the shareholders are not well related to the interests of the board of directors. The board of directors see the company as their main source of income whereas the shareholders want a good return on their investment. Therefore CEO pay levels are supposed to motivate the board of directors to do their work well to create the desired shareholder value (James, 2014). Studies on executive pay have also revealed that the total control or power that the board of directors wield, enable them to award themselves hefty salaries (James, 2014: Roe, 2003). When the CEO and the board of directors give themselves hefty salaries, shareholders need to respond and address this, "moral hazard" quickly in order to prevent the escalation of the agent problem (James 2014;Antle and Smith,1985).

\subsection{Corporate Governance and CEO Pay}

The structure of corporate governance in both public and private companies is a key factor in determining executive pay levels (Jensen, 1993). A typical board consists of the chairperson who is a non-executive director and the CEO who supervisors the executive directors. One of the responsibilities of the CEO is to hire both outside and inside directors. The CEO wields more power in the board, when compared to the chairperson, and other directors (Jensen, 1993). This means that both inside and outside directors are not effective when it comes to putting in place the required executive pay structures (Crystal, 1991). Several studies have been carried out to establish the relationship between CEO pay and board composition (Core et al, 1999). There is a positive relationship between executive pay and board composition (Boyd, 1994). Some studies have revealed the idea that there is a positive correlation between executive pay and board composition (Lambert et al, 1993). Rosenstein and Wyatt (1990) argue that the presence of external directors in the board has the effect of increasing 
shareholder value.

\subsection{Firm Size and CEO Pay}

Lambert et al (1993) argues that the size of the firm cannot be the determining fact of CEO pay for reasons that the CEO may deliberately create a huge board that can easily diminish shareholder return on investment. Lambert et al (1993) goes further to say that the director cannot increase his or her own pay level by enlarging the company. However, numerous studies have shown that there is a positive relationship between CEO pay and firm size (Lambert et al, 1993). Some studies have revealed that there is no correlation between firm size and executive pay. Lambert et al, (1993) argues that there is no association between company performance and firm size.

\subsection{Institutional Shareholders versus CEO Pay}

Hartzell and Starks (2005) in James (2014) identify several types of shareholders, who include institutional shareholders, small private shareholders, large private shareholders and corporate shareholders. Institutional shareholders have certain demands on the board of directors and these demands are; good return on investment, an increase in dividends, growth prospects and an increase in share price. Several studies have shown that companies that have a higher level of institutional investors are associated with poor CEO compensation (Hartzell and Starks, 2003). Institutional investors have the capacity to monitor the activities of the management and this interaction gives the institutional investors the needed capacity to control CEO pay levels. Hartzell and Starks, (2003).Sheifer and Vishny(1986) posit that institutional investors can provide incentives in order to align the interests of the board of directors to the interests of shareholders and such incentives have cost implications. Hartzell and Starks (2003) argue that the presence of institutional investors correlates highly with firm performance and not CEO pay.

\section{Conclusion}

Three approaches were used to explain the processes that are undertaken to determine executive pay. The three approaches made use of the value approach, the symbolic approaches and the agency theories to explain the different conditions under which executive pay levels are considered. The theories do not capture all the conditions and other arrangements that are used by the board of directors to establish executive pay levels. Executive pay levels are socially constructed and this accounts for the inherent disparities in the executive pay levels obtainable in different organisations. The theories do not explain the main causes of the agency problem in most organisations. CEO pay is a function of several factors, such as, board structure, firm size, the presence of outside directors, and the influence of institutional investors. Market forces are also a critical ingredient in determining CEO pay.

\section{References}

Aggarwal, R. K., \& Samwick, A. A. (1999). The other side of the trade-off :the impact of risk on executive compensation. Journal of Political Economy, 10(7), 65-105. https://doi.org/10.1086/250051 
Aguilera, R. V., \& Jackson, G. (2003). The Cross-National Diversity of Corporate Governance: Dimensions and Determinants. The Academy of Management Review. 28(3), 447-465. https://doi.org/10.5465/amr.2003.10196772

Antle, R., \& Smith, A. (1985). Measuring executive compensation: Methods and an application', Journal of Accounting Research, 23(4), 296-325. https://doi.org/10.2307/2490920

Balsam, S. ( 2002). An Introduction to Executive Compensation. San Diego: Academic Press. Balsam, S. (2002). An Introduction to Executive Compensation. Sam Diego: Academic Press. Barkema, H. G., \& Gomez-Mejia, L. R. (1998). Managerial Compensation and Firm Performance: A General Research Framework. Academy of Managemen Journal, 41(2), 135-145. https://doi.org/10.2307/257098

Berkema, H. G., \& Gomez-Mejia, L. R. (1998). Managerial Compensation and Firm Performance: A General Research Framework. Academy of Management Journal, 41(2), 135-145. https://doi.org/10.2307/257098

Boyd, B. K. (1994). Board Control and CEO Compensation. Strategic Management Journal, 15(5), 335-344. https://doi.org/10.1002/smj.4250150502

Brick, I., Palmon, O., \& Wald, J. (2005). CEO compensation, director compensation, and firm performance: evidence of cronyism? Journal of Corporate Finance, 12, 403- 423. https://doi.org/10.1016/j.jcorpfin.2005.08.005

Cicsel, D., \& Carrol, T. (1980). The determinants of executive salaries: An econometric survey. Review of Economics and Statistics, 7(62), 7-13.

Combs, J. G., \& Skill, M. S. (2003). Managerialist and Human Capital Explanations for Key Executive Pay Premiums: A Contingency Perspective. The Academy of Management Journal, 1(3), $76-98$.

Core, J. E., Holthausen, R. W., \& Larcker, D. F. (1999). Corporate governance, chief executive officer compensation, and firm performance. Journal of Financial Economics, 51(3), 371-406. https://doi.org/10.1016/S0304-405X(98)00058-0

Crystal, G. (1991). In search of excess: The overcompensation of American executives. W.W. Norton and Company, New York.

Donaldson, L., \& Davis, J. H. (1991). Stewardship Theory or Agency Theory: CEO Governance and Shareholder Returns. Australian Journal of Management, 16(1), 49-64. https://doi.org/10.1177/031289629101600103

Eisenhardt, K. M. (1989). Agency theory: An assessment and review. Academy of Management Review, 14(3), 57-74. https://doi.org/10.5465/amr.1989.4279003 
Finkelstein, S., \& Boyd, B. K. (1998). How much does the CEO matter? The Role of Managerial Discretion in the Setting of CEO. Compensation. The Academy of Management Journal, 41(2), 179-199.

Finkelstein, S., \& Hambrick, D. C. (1988). Chief executive Compensation: A synthesis and reconciliation. Strategic Management Journal, 9(6), 543-558. https://doi.org/10.1002/smj.4250090603

Frank, R. H. (1984). Are workers paid their marginal products?: American Economic Review, (74), 549-571.

Frey, B. S. (1997). On the relationship between intrinsic and extrinsic work motivation. International Journal of Industrial Organisation, 15(4), 427-439. https://doi.org/10.1016/S0167-7187(96)01028-4

Frydman, C., \& Jenter, D. (2010). CEO Compensation, National Bureau of Economic Research Working Paper Series.

Gomez-Mejia, L. R. (1994). Executive Compensation: A Reassessment and a Future Research Agenda. Research in Personnel and Human Resources Management, 12(3), 161-222.

Gomez-Mejia, L. R., \& Wiseman, R, M. (1997). Reframing Executive Compensations: An Assessment and Outlook. Journal of Management, 23(3), 291-374. https://doi.org/10.1016/S0149-2063(97)90035-0

Goodman, P. S. (1974). An examination of Referents used in the Evaluation of Pay. Organisational Behaviour and Human Performance, 12(3), 170-195. https://doi.org/10.1016/0030-5073(74)90045-2

Greenberg, J. (1986). Determinants of Perceived Fairness of Performance Evaluations. Journal of Applied Psychology, 71(2), 340-342. https://doi.org/10.1037/0021-9010.71.2.340

Hartzell, J. C., \& Starks, L. T. (2005). Institutional investors and executive compensation. The Journal of Finance, 58(6), 2351-2374. https://doi.org/10.1046/j.1540-6261.2003.00608.x

James, P. C. (2014). A Review of the Current Literature on Executive Compensation, New Insights and Understandings. Journal of Economics and Financial Studies, 03(02), 45-54. https://doi.org/10.18533/jefs.v2i02.134

Jensen, C. M., \& Meckling, H. W. (1976). Theory of the firm: managerial behaviour agency costs, an ownership structure. Journal of Financial Economics, 3(9), 360-395. https://doi.org/10.1016/0304-405X(76)90026-X

Jensen, C. M., \& Murphy, J. K. (1990). CEO incentives- It's not how much you pay, but how. Havard Business Review, 3(7), 138-153. https://doi.org/10.1111/j.1745-6622.1990.tb00207.x

Jensen, M. (1993). The modern industrial revolution, exit, and the failure of internal control systems. Journal of Finance, 831-880. https://doi.org/10.1111/j.1540-6261.1993.tb04022.x 
Jensen, M., \& Murphy, K., (2004). Performance pay and top-management incentives. The Journal of Political Economy, 8(2), 34-55.

Jenson, M. C., \& Murphy, K. J. (2004). Remuneration: Where we have been, How we got to Here, What are the Problems, and How to Fix Them? ECGI Working Paper 44/2004.

Kaplan, S. N. (1990). Top Executive Rewards and Firm Performance: a Comparison of Japan and the United States. The Journal of Political Economy, 102(3), 510- 546. https://doi.org/10.1086/261944

Kay, N. (2000). Searching for the Firm: The Role of Decision in the Economics Organisations. Industrial and Corporate Change, 9(4), 683-707. https://doi.org/10.1093/icc/9.4.683

Kidder, D. L., \& Buchholtz, K. (2002). Can Excess Bring Success? CEO Compensation and the Psychological Contract. Human Resources Management Review, 12(4), 599-617. https://doi.org/10.1016/S1053-4822(02)00071-2

Kim, I., \& Tucker, C. M., (2014). What drives CEO pay in the U.S.?: An empirical study of companies in the consumer staples sector. Paper presented at the PPBR conference, California, U.S.A.

Lambert, R. A., Larcker, D. F., \& Verrecchia, R. E. (1993). Portfolio considerations in valuing executive compensation. Journal of Accounting Research, 29(1), 129-149. https://doi.org/10.2307/2491032

Lazear, E. P., \& Rosen, S. (1981). Rank-Order Tournaments as Optimum Labour Contracts. The Journal of Political Economy, 89(5), 841-864. https://doi.org/10.1086/261010

Murphy, K. J. (1999). Chapter 38 Executive Compensation. In C.A. Orley and C. David (EDs). Handbook of Labour Economics, 3, 2485-2563. https://doi.org/10.1016/S1573-4463(99)30024-9

O’Reilly, C. A., Main, B. G., \& Crystal, G. S. (1988). CEO-Compensation as Tournament and Social Comparison: a Tale of Two Theories. Administrative Science Quarterly, 2(4), 23-47.

Ozkan, N. (2007). Do corporate governance mechanisms influence CEO compensation? An empirical investigation of UK companies. Journal of Multinational Financial Management, 17(5), 349-364. https://doi.org/10.1016/j.mulfin.2006.08.002

Parijat, P., \& Bagga, S. (2014). Victor Vroom's Expectancy Theory of Motivation - An Evaluation. International Research Journal of Business and Management, 7(9), 1- 8.

Prendergast, C. (1999). The consequences and issues of executive pay. Journal of Economic Literature, 37(1), 7-63. https://doi.org/10.1257/jel.37.1.7

Roberts, D. R. (1956). A General Theory of Executive Compensation Based on Statistically Tested Proposition. Quarterly Journal of Economics, 70(2), 270- 294. https://doi.org/10.2307/1884268 
Roe, M. J. (2003). Political Determinants of Corporate Governance: Political Context, Corporate Impact. Oxford: Oxford Press.

Rosen, S. (1981). Contracts and the market for executives. In L. Werin and H. Wijkander (Eds.), Contract Economics, Oxford: Blackwell, pp. 181-211.

Rosenstein, S., Jeffrey, G., \& Wyatt, C. (1990). Outside Directors, Board Independence, and Shareholder Wealth. Journal of Financial Economics, 26(2), 175-91. https://doi.org/10.1016/0304-405X(90)90002-H

Shah, S. et al (2009), Determinants of CEO compensation. Empirical evidence from Pakistan listed companies. International research Journal of finance and economies, 32(12), 149-159.

Shleifer, A., \& Vishny, R. W. (1986). Large shareholder and corporate control. Journal of Political Economy, (94), 461-488. https://doi.org/10.1086/261385

Simon, H. A. (1957). The Compensation of Executives. Sociometry, 20(1), 32-35. https://doi.org/10.2307/2786111

Thomas, R. S. (2002). Explaining The International CEO Pay Gap: Board Capture or Market Driven?: Vanderbilt University Law School, Law and Economics Working Paper 02-19.

Tosi, H. L. (2000). How much does performance matter? A-Meta- analysis of CEO pays studies. Journal of management, $\quad 26(2), \quad 301 \quad 339$. https://doi.org/10.1177/014920630002600207

Ungson, G. R., \& Steers, R. M. (1984). Motivation and politics in Executive Compensation. The Academy of Management Review, 9(2), 313-323. https://doi.org/10.5465/amr.1984.4277666

Zhou, X. (2000). CEO pay, firm size, and corporate performance: evidence from Canada. Canadian Journal of Economics, 33, 213-252. https://doi.org/10.1111/0008-4085.00013

Zingales, L. (1998). Corporate Governance. In P. Newman (Ed). The New Palgrave Dictionary of Economics and the Law. New York: Palgrave MacMillan, Basingstoke. https://doi.org/10.2139/ssrn.46906

Zingales, L. (1998). Corporate Governance. In P. Newman (Ed.), The New Palgrave Dictionary of Economics and the Law. New York: Palgrave MacMillan, Basingstoke. https://doi.org/10.2139/ssrn.46906

\section{Copyright Disclaimer}

Copyright for this article is retained by the author(s), with first publication rights granted to the journal.

This is an open-access article distributed under the terms and conditions of the Creative Commons Attribution license (http://creativecommons.org/licenses/by/4.0/). 